\title{
NANOPLASTICS AS A POTENTIAL ENVIRONMENTAL HEALTH FACTOR: FROM MOLECULAR INTERACTION TO ALTERED CELLULAR FUNCTION AND HUMAN DISEASES
}

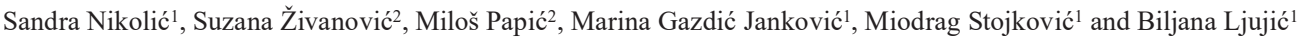

${ }^{I}$ University of Kragujevac, Serbia, Faculty of Medical Sciences, Department of Genetics

${ }^{2}$ University of Kragujevac, Serbia, Faculty of Medical Sciences, Department of Dentistry

\section{NANOPLASTIKA KAO POTENCIJALNI ZDRAVSTVENI FAKTOR ŽIVOTNE SREDINE: OD MOLEKULARNE INTERAKCIJE DO IZMENJENE ĆELIJSKE FUNKCIJE I LJUDSKIIH BOLESTI \\ Sandra Nikolić ${ }^{1}$, Suzana Živanović², Miloš Papić ${ }^{2}$, Marina Gazdić Janković ${ }^{1}$, Miodrag Stojković1 i Biljana Ljujić1 \\ ${ }^{1}$ Univerzitet u Kragujevcu, Fakultet medicinskih nauka, Katedra za genetiku, Kragujevac, Srbija \\ ${ }^{2}$ Univerzitet u Kragujevcu, Fakultet medicinskih nauka, Stomatološki odsek, Kragujevac, Srbija}

\begin{abstract}
The problem of plastic pollution is becoming increasingly important and has attracted great interest in the last few years. Polystyrene is one of the most used plastic types in the food and beverage industry, medical and laboratory devices. Increased plastic production and increased food, water, and air pollution and contact with nanoplastics may cause long-lasting changes and predispose to adverse developmental and degenerative diseases through mechanisms that are not yet understood.

The aim of this article is to provide an overview of current knowledge to plastics, especially polystyrene, and their impact on the human health. In particular, we discuss the major sources of plastic waste, polystyrene surface chemistry, as well as mechanisms by which plastics degrade in the environment. We also provide an insight into cellular uptake mechanism and the molecular interaction of polystyrene nanoparticles and human cells. This review offers scientists and clinicians useful information and could be used as a starting point for more in-depth analysis of nanoplastics as a potential environmental health factor.
\end{abstract}

Keywords: nanoplastics, polystyrene, human diseases.

\section{SAŽETAK}

Problem zagađenja plastikom postaje sve važniji i privlači veliko interesovanje u poslednjih nekoliko godina. Polistiren je jedna od najčešće korišćenih vrsta plastike u industriji hrane $i$ pića, medicinskim i laboratorijskim uređajima. Povećana proizvodnja plastike i povećano zagađenje hrane, vode $i$ vazduha $i$ kontakt sa nanoplastikom mogu uzrokovati dugotrajne promene $i$ predisponirati neželjene razvojne i degenerativne bolesti putem mehanizama koji još uvek nisu razumljivi.

Cilj ovog članka je da pruži pregled trenutnih saznanja o plastikama, posebno polistirenu, $i$ njihovog uticaja na ljudsko zdravlje. Konkretno, razgovaramo o glavnim izvorima plastičnog otpada, površinskoj hemiji polistirena, kao i mehanizmima razgradnje plastike u životnoj sredini. Takođe pružamo uvid $u$ ćelijski mehanizam usvajanja $i$ molekularnu interakciju polistirenskih nanočestica i ljudskih ćelija. Ovaj pregled nudi naučnicima i kliničarima korisne informacije i mogao bi da se koristi kao polazna osnova za detaljniju analizu nanoplastike kao potencijalnog zdravstvenog faktora životne sredine.

Ključne reči: nanoplastika, polistiren, ljudske bolesti. 


\section{INTRODUCTION}

Plastic production grows continuously, currently reaching around 350 million tons per year $(1,2)$. Being a material with diverse physical and chemical characteristics that are easily changeable, has made plastic ubiquitous and necessary in everyday life, and distributed worldwide (2). Over $40 \%$ of plastic is used as single-use packaging including those for baby bottles, food containers, and medical applications. Therefore, it is not surprising that plastic particles have been detected in rain, air, soil, snow, salt, tap/bottled water, beer, tea, and food (3). Ongoing pandemic with the COVID19 has increased the complexities of plastic waste management. In fact, the fear of the transmission and governmental regulations around the world had led to the increase in the use of personal hygiene products, personal protective equipment, and single use containers and bags, and thus to the overall increase in plastic waste. (Figure 1). The inadequacies of current waste management systems and the increased dependence on plastic could trigger a new environmental crisis (4). There is growing evidence that the current use and management of plastics lead to significant environmental pollution, already discussing plastic waste as the number one new global enemy $(2,5,6)$. Due to the concern for the environment, the problem of plastic pollution is becoming increasingly important and has attracted great interest in the last few years (7).

The aim of this article is to provide an overview of current knowledge to plastics, especially polystyrene, and their impact on the human health.

Figure 1. The sources of plastic waste in COVID-19 pandemic

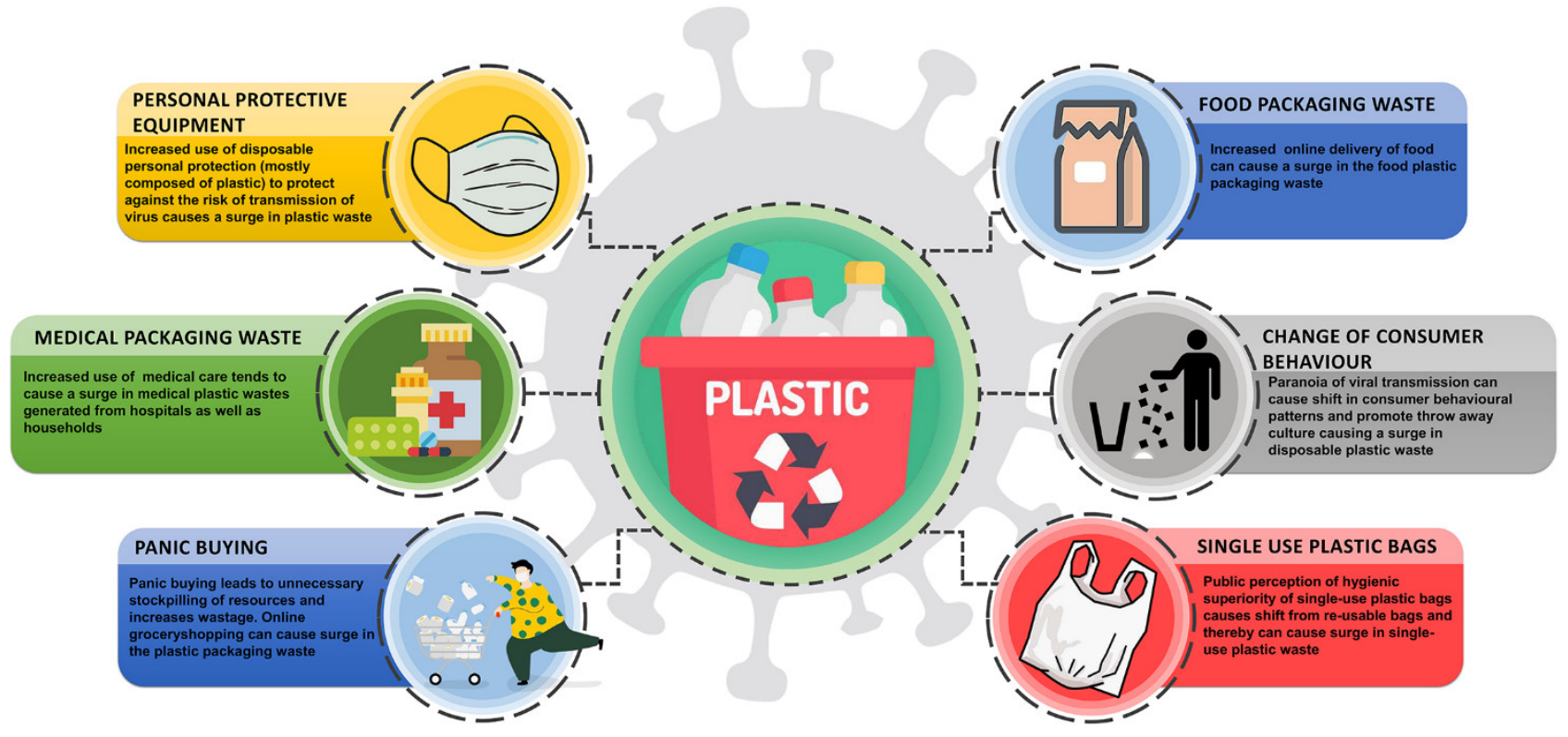

\section{PLASTICS CHEMISTRY AND BIODEGRADATION}

Different types of plastics are compounds of high molecular weight made from polymerized monomers with the addition of plasticizers, stabilizers, pigments and other additives (8). Synthetic organic polymers mostly comprise plastics that are in use today. Those polymers include polystyrene, high and low-density polyethylene, , polyethylene terephthalate, polypropylene, and polyvinyl chloride (9). Out of all, polystyrene (PS) is the most commonly used type of plastic. PS is formed as a result of styrene polymerization (Figure 2), while styrene is produced by catalytic dehydrogenation of ethylbenzene (8). PS particles can be easily synthesized with a broad range of sizes and various surface modifications $(8,10)$. Because the surface of PS is hydrophobic, it can be easily modified by, for example, oxidation (11). Other than being easily manipulated, PS plastics may also be sterilized, which makes them suitable for cell cultures and the use in research (8).

PS is a thermoplastic polymer characterized by high translucency, durability and may be easily dyed (12). Global polystyrene capacity in 2016 was 14.7 megatons and Europe and North America are, after China, the biggest producers of polystyrene (16.3\% and $17 \%$, respectively; https://www. plas ticsinsight.com/resin-intelligence/resin-prices/polystyrene). PS is very frequently used for medical applications including medical devices, petri dishes, pipettes, containers for drugs and cell-growth media (Table 1). More importantly, it is also used for the production of the Styrofoam, a material widely used in the production of single use trays, plates, and cups. It is also used for food and products storage and packing, as 
well as in the production of toys, office supplies etc $(8,12)$. As a result of its prevalence, PS is a leading environmental pollutant from plastic waste (13); . Surprisingly, PS can be found as sodium PS sulfonate or Kayexalate ${ }^{\circledR}$ (generic brands Kalexate, Kionex, and SPS) which is a drug prescribed to treat hyperkalemia, and it is also used for treatment of pediatric patients and nursing mothers (Table 1). Unfortunately, there are no studies on Kayexalate's nonclinical toxicology, carcinogenesis, mutagenesis, and impairment of fertility.

Figure 2. The process of polystyrene formation through styrene polymerization

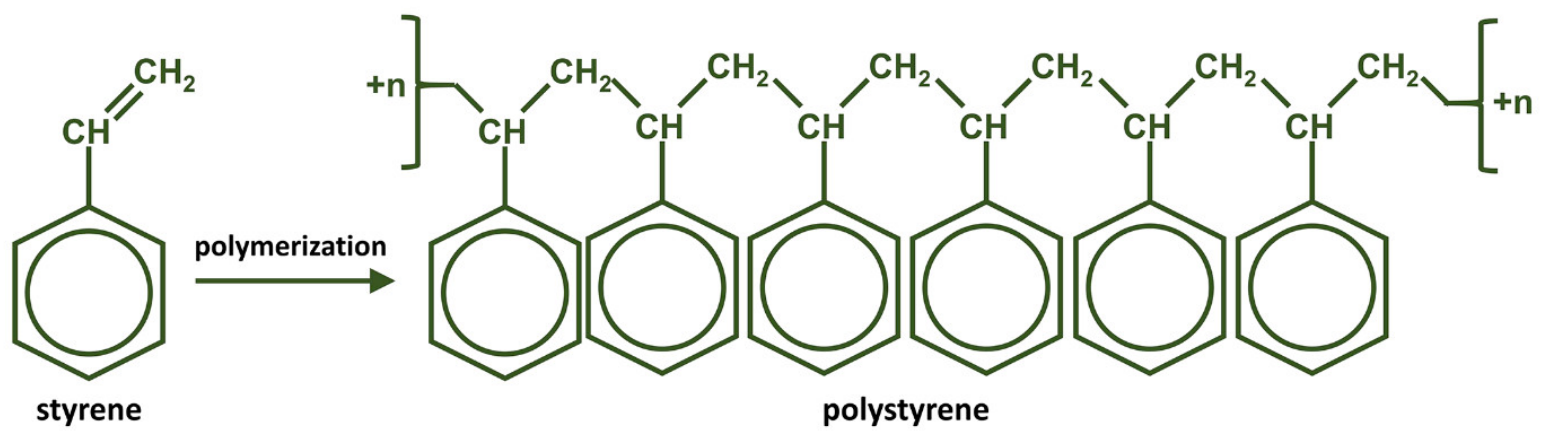

Table 1. Polystyrene in everyday life

\begin{tabular}{|l|l|}
\hline In appliances & Refrigerators, air conditioners, washers, microwaves, vacuum cleaners, blenders \\
\hline In electronics & Parts for televisions, telecomunication devices, computers and other IT equipment \\
\hline In insulation & Building walls and roofing, refrigerators and freezers, industrial cold storage facilities \\
\hline In packaging & $\begin{array}{l}\text { CD and DVD cases, foam packaging, food packaging, egg cartons, single use trays, } \\
\text { plates and cups }\end{array}$ \\
\hline In medical & $\begin{array}{l}\text { Tissue culture trays, test tubes, petri dishes, pipettes, diagnostic components, housings } \\
\text { for test kits and medical devices, containers for drugs and cell-growth media }\end{array}$ \\
\hline In medicine & Kayexalate $^{\circledR}$ (available in USA) \\
\hline
\end{tabular}

Most conventional plastics, including polystyrene, are not biodegradable. However, styrene, cumene and ethylbenzene can be detected in the air. The US Environmental Protection Agency determined the value of $300 \mathrm{ppm}\left(1000 \mathrm{mg} / \mathrm{m}^{3}\right)$ of styrene as the highest admissible in the case of a chronic exposure (13). PS particles were also found in atmosphere of mountain regions remote of the major cities (14). The degradation of PS in enviormment is plausable, but to a certain degree. Exposure to high temperature results in complete dissolution fo PS plastics, but only at the temperatures over $330^{\circ} \mathrm{C}$, with styrene monomer being the main product. However, in the enviorment, plastic objects can not disolve but can degrade into smaller pieces by a combination of chemical and physical processes including photodegradation, oxidation, hydrolytic degradation, and mechanical disintegration. . Photodegradation by the ultraviolet radiation leads to breaking of chemical bonds in synthetic polymers causing a reduction of the polymer's molecular weight and leads to a reduction in its mechanical strength, making it more susceptible to brakeing. In fact, over time, plastic is being fragmented into smaller pieces by external mechanical forces. The resulting plastic pieces form a highly heterogeneous collection varying in size, shape, and density as well as in the chemical composition of the specific material $(15,16)$.
Intentionally produced (primary plastic) or after degradation/aging (secondary plastic), the plastic waste in nature appears as macroparticles, microparticles (MPs) and nanoparticles (NPs) (17). According to EU Independent Expert Report on "Environmental and Health Risks of Microplastic Pollution" from 06/2019, MPs are defined as solid syntheticpolymer-containing particles less than $5 \mathrm{~mm}$ in their longest dimension, while NPs have a longest dimension of up to $100 \mathrm{~nm}$. Due to their small size and low degradation, MPs can reach atmospheric air, disrupt the food chain and have adverse effects on the environment. NPs are characterized by a higher ratio of surface to volume, which has an important impact on their reactivity (17). These particles can be easily physically or chemically absorbed into various eviormmental elements, such as persistent organic pollutants and hevy metals, as well as into microbes and living organisms. These processes of physical and chemical changes in NPs can occur naturally or by synthesis which is currently extensively used in industry. These types of industrially obtained NPs are called engineered nanoparticles (ENPs) (Figure 3). 
Figure 3. Most common types of engineered and natural nanoparticles (ENPs)

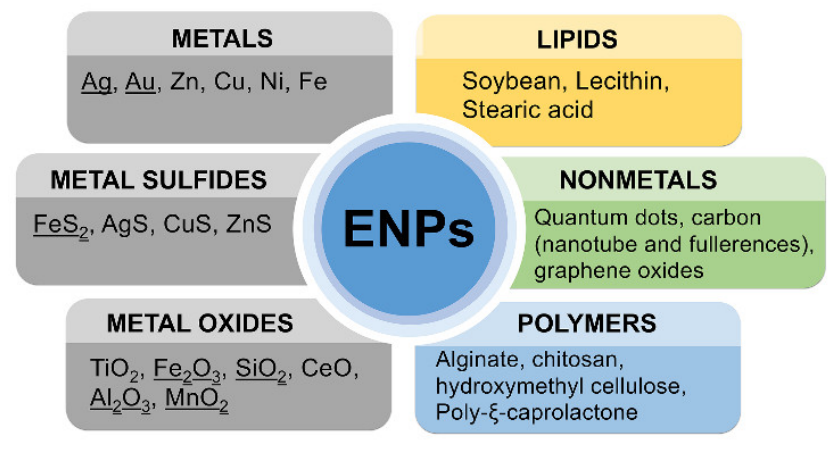

\section{INTRACELLULAR UPTAKE OF PLASTIC NANOPARTICLES}

The cellular uptake of NPs mainly depends on their interactions with biomacromolecules including and depends on their diameter, chemical structure, and polarity. Binding of proteins from biological fluids on nanoparticle surfaces induces formation of a "protein corona" around the particle which defines the cytotoxicity, body distribution, and endocytosis of NPs into specific cells (18). Currently, there are no data which confirm the presence of plastic NPs in human body. However, nanosized plastic can be integrated into the animal food chain, and also into the human food chain (19). Recent studies have shown that different classes of NPs can pass mucosal barrier and enter circulation, leading to direct cell damage and harmful systemic effects (17). Under in vitro conditions, nanosized plastic enters the cells via different mechanisms (10). The NPs were internalized rapidly via clathrin-mediated endocytosis, phagocytosis, clathrin- and caveolae-independent endocytotic pathways, caveolae-mediated endocytosis, macropinocytosis (20) and their accumulation in intracellular vesicles resulted in generation of high levels of reactive oxygen species (ROS). ROS is usually marked as the main cause of NPs' potential toxicity affecting cell membrane and causing cellular stress (21), lysosomal destabilization, apoptosis (22), and mTOR-dependent autophagy. Autophagy is an intra-cellular mechanism crucial for removal and recycling of damaged and/or outlived cellular components, which constitute the autophagy cargo. The cargo is engulfed in cytosolic vesicles, named autophagosomes, and delivered to lysosome (23). Recycling of organelles, cell membranes and proteins is an important process for regulation of cell homeostasis as well as for tissue remodeling during embryogenesis. Abnormal autophagy contributes to various disorders, such as tumor and neurodegeneration, and to the changes in response to environmental stress stimuli (24). Indeed, the presence of NPs in human renal cells (25), dopaminergic neural cells (26), and human keratinocytes (27) led to the generation of ROS which is associated with excessive cell death by apoptosis and autophagy. If the removal of damaged cellular compounds, via the ubiquitinproteasome system (UPS) and/or the autophagy/lysosome pathway, is impaired, the main requirement for the preservation of cell homeostasis is consequently missing (23) (Figure 4). However, further research is needed as all transmission paths, and accumulation and interaction of NPs with the environment, especially with living organisms, remains unclear.

Figure 4. Schematic representation of different ways in which NPs could disturb the cellular components

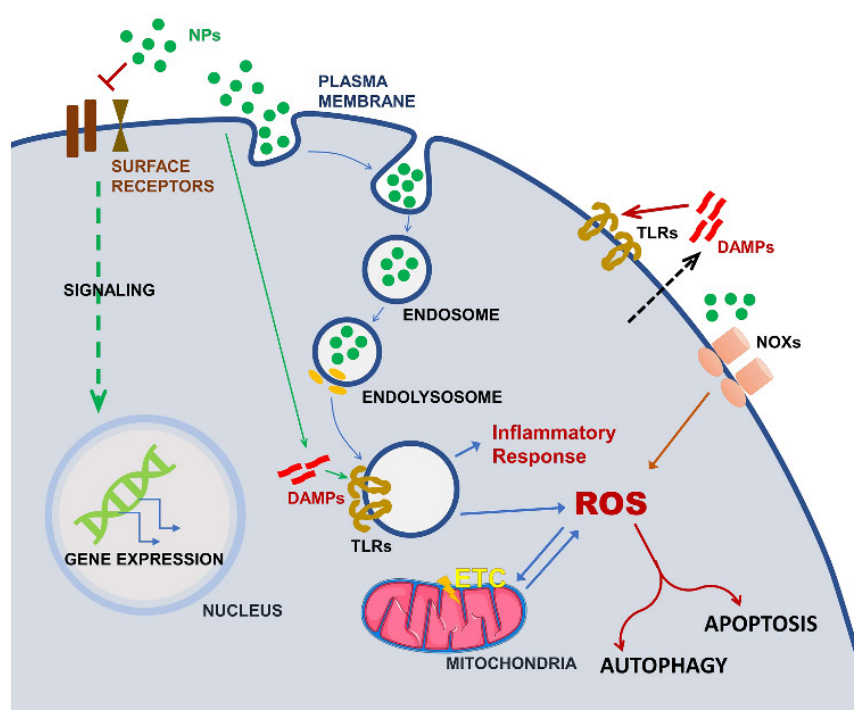

NPs could damage the plasma membrane, but could also affect the signaling of cell surface receptors and alter gene expression in the nucleus. Endocytosed NPs could disturb the endocytic pathway and compromise the endosomal membranes causing stress and disruption of endolysosome followed by the production of ROS and the formation of endogenous and secreted DAMPs. DAMPs could further activate intra- or extra-cellular TLRs and lead to the activation of cellular inflammatory response. ROS production could also be induced from NOXs. Mitochondrial damage, either by NPs through ETC damage or in response to oxidative stress, could increase the production of ROS. Increase in ROS production in either way could induce cellular death through apoptosis or autophagy. Abbreviations: NPs - nanoparticles; ROS - reactive oxygen species; DAMPs - damage associated molecular patterns; TLRs - tool-like receptors; NOXs - NADPH oxidases; ETC - electron transport chain.

\section{HARMFUL EFFECTS OF NANOPLASTICS ON HUMAN HEALTH}

Increased plastic production and increased food, water, and air pollution and contact with nanoplastics may cause long-lasting changes and predispose to adverse human developmental, genetic and immune diseases through mechanisms that are not yet understood. Entry of NPs in the living organisms usually happens by the respiratory tract, digestive system, or through the skin. Because of the hydrophobic nature of the plastic polymers, nanoplastic diffusion through intact skin is very low. Nevertheless, additional pathways of entry 
for NPs through the skin are hair follicles, apocrine ducts, and skin abrasions $(28,29)$.

Thus, the study of the interaction of human cells with PSNPs can demonstrate relevance of the data obtained in animal models and provide us with an early indication of the effect of a polystyrene on the human body. Prietl et al. (30), showed that $20 \mathrm{~nm}$ PS-NPs are rapidly fagocyted by human monocytes and exert profound cytotoxicity. They have also shown that PS-NPs of 100 and $1000 \mathrm{~nm}$ diameters stimulate the production of soluble factors such as IL- 6 and IL- 8 by immune cells, and could cause oxidative burst and production of high levels of ROS in monocytes (30). The polypropylene MPs also significantly stimulated the synthesis of pro-inflammatory mediators IL- 6 and TNF- $\alpha$ in human peripheral blood leukocytes, and activated mastocytes to secrete histamine (31). Thus, plastic can trigger immune response by promoting cell-mediated immunity, however potential long-term effects on cellular and tissue homeostasis have to be further investigated. Moreover, it is crucial to overcome the knowledge gap between environmental relevant concentrations and the level of PS-NPs detected in the living systems (32).

There is a scarce number of studies which elucidate the adverse impact of plastic pollution on early human development and epigenetics. Most recently we developed a novel platform to investigate whether PS-NPs can alter gene expression and affect biological properties of preimplantation human embryos and human induced pluripotent stem cells (hiPSCs) (12). Genes required for left-right axis determination, LEFTY1 and LEFTY2, which encode members of the transforming growth factor-beta superfamily of proteins were down-regulated while several genes involved in visual system development were up-regulated in both cell samples (12). Our study indicated that PS-NPs treatment significantly impaired structure of extracellular matrix and induced malformations of the atrioventricular heart valves. We applied the HiPathia program and predicted that PS-NPs increase the risk for ischemic heart disease by altering $A P O C 3$ circuit (12).

It is well known that gene defects have a key role in the onset and progression of neurological disorders. During the last decades, broad range of genetic studies revealed the molecular basis and pathophysiology of neurodegenerative diseases including autism, sensorineural hearing loss, macular degeneration, progressive forms of dementia, primary parkinsonism, Huntington's chorea, etc. It should not be overlooked, as Tanzi et al. (33) found, that inhalation of fine particulate air pollution is the risk factor for neurodegenerative disorders and that fetus disease burdens also increase after maternal exposure to environmental pollution. Deciphering and defining these mechanisms is of great importance, as the increase of our understanding of the fundamental biology behind these processes could lead to the development of new strategies to prevent and treat pollution related human disorders.

\section{CONCLUSIONS AND FUTURE PROSPECTIVE}

For decades, we have been observing a rapid increase in plastic production in the world. This has shown great consequences on living organisms. Therefore, future studies should focus on various plastic materials, their appropriate concentrations and effects of chronic exposure to them for risk assessment on the environment and human health. Gained information through those studies could support active measures of international organizations in reduction of plastic production, controlling its environmental degradation, and in protecting the health of living organisms.

In future prospective, a strategy should be developed with an ambitious approach adopting the role of science in plastic policy making, encouraging new rules on prevention of plastic pollution, plastic replacement and recyclability. The benefits of this approach will be obvious for the scientific field, environmental medicine, human health, regulators, environment, and laypersons: better understanding of health impacts of exposure to plastics; innovative approaches in human health risk assessment; new laws and regulations in environmental protection.

\section{ACKNOWLEDGMENTS}

This work was supported by Serbian Ministry of Science (ON175103) and Faculty of Medical Sciences University of Kragujevac JP25/19, JP 02/08 and JP 04/12.

The authors declare that there is no conflict of interest regarding the publication of this article.

\section{REFERENCES}

1. Plastics Europe. Plastics - the facts 2018: an analysis of European plastics production, demand and waste data [Internet]. 2018. Available from: https://www.plasticseurope.org/download file/force/2387/319

2. Heidbreder LM, Bablok I, Drews S, Menzel C. Tackling the plastic problem: A review on perceptions, behaviors, and interventions. Sci Total Environ. 2019;668:107793.

3. Andreani G, Cannavacciuolo A, Menotta S, Spallucci V, Fedrizzi G, Carpenè E, et al. Environmental exposure to non-essential trace elements in two bat species from urbanised (Tadarida teniotis) and open land (Miniopterus schreibersii) areas in Italy. Environ Pollut. 2019;254(Pt B):113034.

4. Vanapalli KR, Sharma HB, Ranjan VP, Samal B, Bhattacharya J, Dubey BK, et al. Challenges and strategies for effective plastic waste management during and post COVID-19 pandemic. Sci Total Environ. 2020;750(1):141514.

5. Bläsing M, Amelung W. Plastics in soil: Analytical methods and possible sources. Sci Total Environ. 2018;612(1):422-35. 
6. Horton AA, Walton A, Spurgeon DJ, Lahive E, Svendsen C. Microplastics in freshwater and terrestrial environments: Evaluating the current understanding to identify the knowledge gaps and future research priorities. Sci Total Environ. 2017;586(1):127-41.

7. Shen M, Zhang Y, Zhu Y, Song B, Zeng G, Hu D, et al. Recent advances in toxicological research of nanoplastics in the environment: A review. Environ Pollut. 2019;252(Pt A):511-21.

8. Kik K, Bukowska B, Sicińska P. Polystyrene nanoparticles: Sources, occurrence in the environment, distribution in tissues, accumulation and toxicity to various organisms. Environ Pollut. 2020;262(1):114297.

9. Lee WS, Cho H-J, Kim E, Huh YH, Kim H-J, Kim B, et al. Correction: Bioaccumulation of polystyrene nanoplastics and their effect on the toxicity of $\mathrm{Au}$ ions in zebrafish embryos. Nanoscale. 2019;11(7):3396.

10. Loos C, Syrovets T, Musyanovych A, Mailänder V, Landfester K, Nienhaus GU, et al. Functionalized polystyrene nanoparticles as a platform for studying bio-nano interactions. Beilstein J Nanotechnol. 2014;5:2403-12.

11. van Midwoud PM, Janse A, Merema MT, Groothuis GMM, Verpoorte E. Comparison of biocompatibility and adsorption properties of different plastics for advanced microfluidic cell and tissue culture models. Anal Chem. 2012;84(9):3938-44.

12. Bojic S, Falco MM, Stojkovic P, Ljujic B, Gazdic Jankovic M, Armstrong L, et al. Platform to study intracellular polystyrene nanoplastic pollution and clinical outcomes. Stem Cells. 2020. [published online ahead of print]. doi:10.1002/stem.3244

13. Xu M, Halimu G, Zhang Q, Song Y, Fu X, Li Y, et al. Internalization and toxicity: A preliminary study of effects of nanoplastic particles on human lung epithelial cell. Sci Total Environ. 2019;694:133794.

14. Allen S, Allen D, Phoenix VR, Le Roux G, Durántez Jiménez P, Simonneau A, et al. Atmospheric transport and deposition of microplastics in a remote mountain catchment. Nat Geosci. 2019;12(5):339-44.

15. Lehner R, Weder C, Petri-Fink A, Rothen-Rutishauser B. Emergence of Nanoplastic in the Environment and Possible Impact on Human Health. Environ Sci Technol. 2019;53(4):1748-65.

16. Da Costa JP, Nunes AR, Santos PSM, Girão A V, Duarte AC, Rocha-Santos T. Degradation of polyethylene microplastics in seawater: Insights into the environmental degradation of polymers. J Environ Sci Health A Tox Hazard Subst Environ Eng. 2018;53(9):866-75.

17. Bouwmeester H, Hollman PCH, Peters RJB. Potential Health Impact of Environmentally Released Micro- and Nanoplastics in the Human Food Production Chain: Experiences from Nanotoxicology. Environ Sci Technol. 2015;49(15):8932-47.

18. Ritz S, Schöttler S, Kotman N, Baier G, Musyanovych A, Kuharev J, et al. Protein corona of nanoparticles: distinct proteins regulate the cellular uptake. Biomacromolecules. 2015;16(4):1311-21.
19. Yang D, Shi H, Li L, Li J, Jabeen K, Kolandhasamy P. Microplastic Pollution in Table Salts from China. Environ Sci Technol. 2015;49(22):13622-7.

20. Grossi M, Morgunova M, Cheung S, Scholz D, Conroy E, Terrile M, et al. Lysosome triggered near-infrared fluorescence imaging of cellular trafficking processes in real time. Nat Commun. 2016;7(1):10855.

21. Bhattacharjee S, Rietjens IMCM, Singh MP, Atkins TM, Purkait TK, Xu Z, et al. Cytotoxicity of surface-functionalized silicon and germanium nanoparticles: the dominant role of surface charges. Nanoscale. 2013;5(11):4870-83.

22. Terman A, Kurz T, Navratil M, Arriaga EA, Brunk UT. Mitochondrial Turnover and Aging of Long-Lived Postmitotic Cells: The Mitochondrial-Lysosomal Axis Theory of Aging. Antioxid Redox Signal. 2010;12(4):503-35.

23. Rodolfo C, Campello S, Cecconi F. Mitophagy in neurodegenerative diseases. Neurochem Int. 2018;117:15666.

24. Galluzzi L, Kepp O, Kroemer G. Enlightening the impact of immunogenic cell death in photodynamic cancer therapy. EMBO J. 2012;31(5):1055-7.

25. Ding F, Li Y, Liu J, Liu L, Yu W, Wang Z, et al. Overendocytosis of gold nanoparticles increases autophagy and apoptosis in hypoxic human renal proximal tubular cells. Int J Nanomedicine. 2014;9(1):4317-30.

26. Afeseh Ngwa H, Kanthasamy A, Gu Y, Fang N, Anantharam V, Kanthasamy AG. Manganese nanoparticle activates mitochondrial dependent apoptotic signaling and autophagy in dopaminergic neuronal cells. Toxicol Appl Pharmacol. 2011;256(3):227-40.

27. Brun E, Barreau F, Veronesi G, Fayard B, Sorieul S, Chanéac $\mathrm{C}$, et al. Titanium dioxide nanoparticle impact and translocation through ex vivo, in vivo and in vitro gut epithelia. Part Fibre Toxicol. 2014;11(1):13.

28. Jatana S, Callahan L, Pentland A, DeLouise L. Impact of Cosmetic Lotions on Nanoparticle Penetration through ex Vivo C57BL/6 Hairless Mouse and Human Skin: A Comparison Study. Cosmetics. 2016;3(1):6.

29. Lane ME. Skin penetration enhancers. Int J Pharm. 2013;447(1-2):12-21.

30. Prietl B, Meindl C, Roblegg E, Pieber TR, Lanzer G, Fröhlich E. Nano-sized and micro-sized polystyrene particles affect phagocyte function. Cell Biol Toxicol. 2014;30(1):1-16.

31. Hwang J, Choi D, Han S, Choi J, Hong J. An assessment of the toxicity of polypropylene microplastics in human derived cells. Sci Total Environ. 2019;684:657-69.

32. Yong CQY, Valiyaveetill S, Tang BL. Toxicity of Microplastics and Nanoplastics in Mammalian Systems. Int J Environ Res Public Health. 2020;17(5):1509.

33. Tanzi RE, Bertram L. Twenty Years of the Alzheimer's Disease Amyloid Hypothesis: A Genetic Perspective. Cell. 2005;120(4):545-55. 